\title{
Tas-de-charge - An Essential Part of Gothic Vault
}

\author{
Krisztina Fehér ${ }^{1 *}$ \\ ${ }^{1}$ Department of History of Architecture and Monument Preservation, Faculty of Architecture, Budapest University of Technology \\ and Economics, H-1111 Budapest, 3 Múegyetem rkp., Hungary \\ * Corresponding author, e-mail: feher.krisztina@epk.bme.hu
}

Received: 20 July 2020, Accepted: 19 January 2021, Published online: 21 April 2021

\begin{abstract}
Gothic architecture can be viewed from several perspectives, including stylistic aspects, architectural theory, and structural analysis. As Gothic architecture is a skeletal construction, it is essential to achieve an equilibrium with the multiple loads and forces. Medieval master masons' architectural knowledge was firmly based on empirical learning, which stimulated the dynamic development of structural innovations.

This paper emphasises and describes a particular type of vault springer, one of the most complicated and sensitive parts of Gothic construction. Known as tas-de-charge, it became especially characteristic of high Gothic architecture. According to its principle, the springer's lower courses contain the merged vault nerves and are carved from one single stone block in each course. The beds of these courses are not radial as those of the average voussoirs, but horizontal. Without the concept of tas-de-charge, the development of late Gothic vaults could not be imaginable. This particular solution made possible the creation of elegantly narrow imposts supporting the vault ribs, the double arch and the formerets. So far, tas-de-charge has not been a focus of interest in the historiography of Hungarian medieval architecture; however, it appears that it was commonly applied in our late Romanesque and early Gothic monuments.
\end{abstract}

\section{Keywords}

tas-de-charge, vault, Gothic, springer, stereotomy, medieval design

\section{Introduction}

Gothic architecture is usually interpreted as a series of structural and constructional innovations. Rib vaults with pointed arches, the system of flying buttresses, and bar traceries are the most well-known of these innovations, that spread quickly from Île-de-France to other parts of Europe by the transfer of architectural and artistic knowledge. In Hungary, early and high Gothic architecture was chiefly based on the influence and import of foreign masters, but besides them, the activity of local lodges was also considerable. Hence, the main question in the study of Hungarian medieval monuments is usually the relationship and influence of different lodges and masters. Admitting this question's importance, it is equally worth examining and understanding how the buildings, especially the details, were designed. From the latter, a series of interesting inquiries can be set up, such as how experienced the master mason was in stereotomy and design, or whether he was aware of the latest structural innovations, and if so, how he adapted them to the local architectural situation.

These skills and creativity can be more efficiently comprehended by paying attention to specific architectural details with rather challenging designs. Gothic structure contains a series of such details, like vaults, flying buttresses, clerestory windows with traceries, and especially the integration of all these elements, which demanded a high standard of skills. Due to their complexity, these are the structures that most commonly appeared in medieval architectural sources, from Villard de Honnecourt's sketchbook (13 ${ }^{\text {th }}$ Century) to Lorenz Lechler's Unterweisung (1516) (see, e.g. Branner, 1963; Holton, 2006).

The vault springer is one of these aspects with challenging design characteristics (Pérez de los Ríos and Rabasa Díaz, 2016; Fehér, 2017). Its geometry, stereotomy and connection to the supports tend to be individual with each Gothic construction. The way the springer was designed and executed resulted from a series of important design decisions, according to the master's level of expertise and sense of creativity (Maira Vidal, 2017).

The current paper focuses on a special type of vault springer, called tas-de-charge. Tas-de-charge can be considered one of the Gothic innovations that revolutionised the construction of ribbed vaults (see Branner, 1963). In Gothic 
skeletal construction, where the charges are born not by thick walls but narrow frames, the resultant thrusts' equilibrium is a question of highly intelligent structural design. Tas-de-charge made it possible to balance and reinforce one of the most vulnerable and complicated parts of Gothic construction: the vault springer. Despite its importance, it has scarcely been a focus of interest in the Hungarian bibliography of architectural history. This paper aims to emphasise its significance by describing its indispensable role in the development of Gothic construction. Another of the paper's intentions is to highlight the earliest Hungarian examples of the particular solution of tas-de-charge.

\section{What is the tas-de-charge?}

According to the principal of the tas-de-charge type vault springer, or so-called vault springer en tas-de-charge, the joints of its lower courses are horizontal instead of radial (Fig. 1). It shares this principle with the corbel arches, which is why Henri Deneux (1943) considered the ancient Near Eastern corbel arches as early forms of tas-de-charge. Besides the horizontal joints, the other feature of the tasde-charge in Gothic quadripartite vaults is that the transversal double-arch, the diagonal ribs and the formerets are merged at the lower part, where the courses are carved from single stone blocks (A, B and C in Fig. 1). In the upper courses, the nerves spring wider and wider, till they are separated and carved typically from independent blocks with radial joints, called voussoirs (D in Fig. 1).

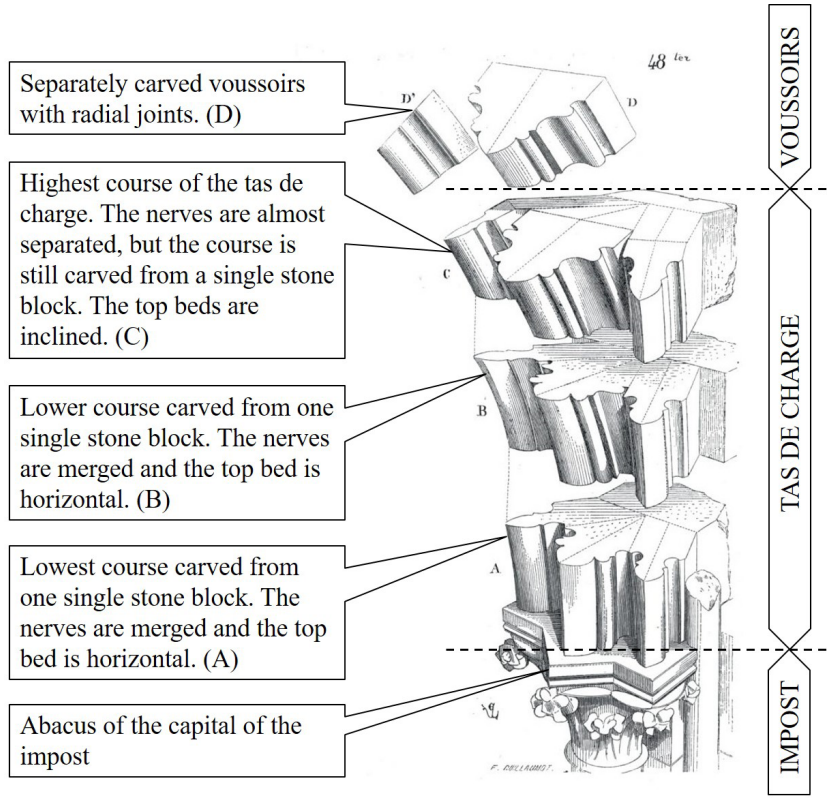

Fig. 1 Principles of the tas-de-charge (original drawing from Viollet-leDuc, 1854-1868 entry Construction / Voûtes)
According to the international bibliography of medieval architecture, there is a terminological confusion about the definition of tas-de-charge. In one terminological system, only the top course of the one-block elements (just below the course of the separated voussoirs, where the lower bed is horizontal, but the top beds are already inclined) is called tas-de-charge ( $\mathrm{C}$ in Fig. 1). In this terminological system, the lower one-block courses (A and B in Fig. 1) are called springers (e.g. see Shelby and Mark, 1979). In the other nomenclature, tas-de-charge stands for the particular type of vault shoulders with horizontal beds and merged nerves. Thus, in other words, the whole shoulder section (A, B and $\mathrm{C}$ in Fig. 1) is produced with tas-de-charge, or after the original French terminology en tas-de-charge (e.g. see Deneux, 1943; Melchior de Vogüé and Neufville, 1971). The terminology becomes more confused with the term springer because it can stand for the lower courses of the tas-de-charge type shoulder, but more frequently the whole vault shoulder is called springer in general, regardless of its type. In this paper, the term tas-de-charge stands for the specific type of shoulder with horizontal beds and merged nerves, while the term springer is used for shoulders in general. The inscriptions of Fig. 1 follow this nomenclature.

\subsection{The development of tas-de-charge}

The first appearance of the tas-de-charge in a medieval building is an inquiry still to investigate. According to Robert Branner (1962; 1963), tas-de-charge was likely first applied in the Cathedral of Chartres's nave vaults as early as around 1205 (Branner, 1962). It shows the vagueness of this hypothesis that Branner himself cited Francis Bond's earlier statement claiming that tas-de-charges had already been employed in Glastonbury in about 1185-1190 (Bond, 1906; Branner, 1962; about early applications see also Jansen, 1982). Branner also expressed the necessity of the mason's high standard stereotomic knowledge for the execution of the tas-de-charge, where all the major geometry of the vaulting to the minor details, including the profile templates, had to be designed beforehand. This was only achievable with carefully measured plans and drawings (Branner, 1963; Pérez de los Ríos and Rabasa Díaz, 2016). Tas-de-charge was a crucial structure in high Gothic rib vaults that readily spread through Europe. Without tasde-charge, the evolution of lierne, tierceron, fan or multicurve vaults could not be imagined. In late Gothic vaults, the development of the tas-de-charge tended to the total intersection or crossing of nerves in the springer, which resulted in such spectacular examples, like Benedict Ried's 
Vladislav Hall in Prague, the Sacristy of the Cathedral of Perpignan (Senent Domínguez et al., 2012), or the Church of Saint Séverin in Paris (Rabasa-Díaz, 2018).

\subsection{The structural role of the tas-de-charge in the construction}

The tas-de-charge was first described in detail by Eugène Emmanuel Viollet-le-Duc (1854-1868) in his 'Rationale dictionary of French architecture from XI th to XVI th century' at the entry 'Construction' and 'Tas de charge'. Besides its proper definition, he interpreted the origins, genealogy and structural advantages of this remarkable solution. He considered it especially useful when several arches arrived on one pillar or column, with a significant vertical force from above (Fig. 2 (a) and (c)). If the lowest springers of the separate arches had oblique beds, the upper vertical charge could crush them sideways (Fig. 2 (a)). The individual forces on the abacus cause lateral tension and cracks in the column capital. For this problem, two solutions can be imagined. One is to increase the distance between the separate arches so that the upper load does not load them significantly. However, in this case, the imposts would require a large surface for all the separate nerves needed to be placed next to each other (Fig. 2 (b)). Viollet-le-Duc considered this an early solution, mainly used in the $12^{\text {th }}$ Century (Viollet-leDuc, 1854-1868 entry Construction / Voûtes). The other way to solve the problem is to approach the arches so that they are merged in the lower unified stone layers (Fig. 2 (c)). In this case, the lower and upper beds are better horizontal instead of radial to resist the upper weights. Tas-de-charge follows the principle of the latter solution (Viollet-le-Duc, 18541868 entry Construction / Voûtes and Tas de charge).

Tas-de-charge is structurally complicated because it is a junction of multiple forces with various directions: a)

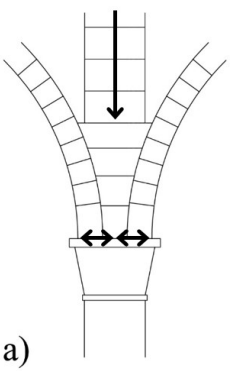

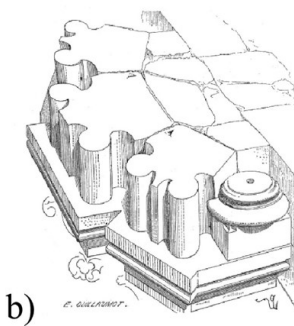

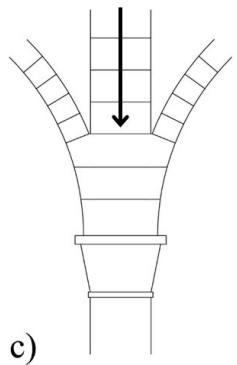

c)
1. the outward thrust of the vault,

2. the counteracting thrust of the buttressing system and

3. the vertical weight of the wall from above (Fig. 3).

Tas-de-charge is a crucial point of the structure where the equilibrium of all these forces must be achieved. The position of the flying buttress is to balance vault thrust and also redirect the upper wall weight resultant in order to get the resultant inside the wall under the tas-decharge. For increasing the stability, the blocks of horizontal joints are bound to the wall. The mass of the tas-decharge, formed by the merged transverse arch, diagonal ribs, and formerets also can be reinforced by masonry fill between the blocks and the wall. The solidity of the tasde-charge serve to stiffen the most vulnerable part of the vault: it withstands and balances the counteracting thrust from outside against the outward thrust of the vaults (Stanley, 2006; see also Fitchen, 1955; Heyman, 1966).

Additionally, due to the tas-de-charge, where the voussoirs start springing from a higher level, the arches become lighter. (Viollet-le-Duc, 1854-1868, entry Tas de charge). The voussoirs' weight could be further reduced by using lighter stones, than the more load-bearing stone of the tas-de-charge. By raising the springing point of the voussoirs, the arches' span is also reduced. As Rocío Maira Vidal (2017) found in Lincoln Cathedral and the Monasteries of Santa María de Huerta and Las Huelgas de Burgos, the top of the tas-de-charges is sometimes raised over the mid-point of the intrados, which could result in an up to one-meter reduction of the span.

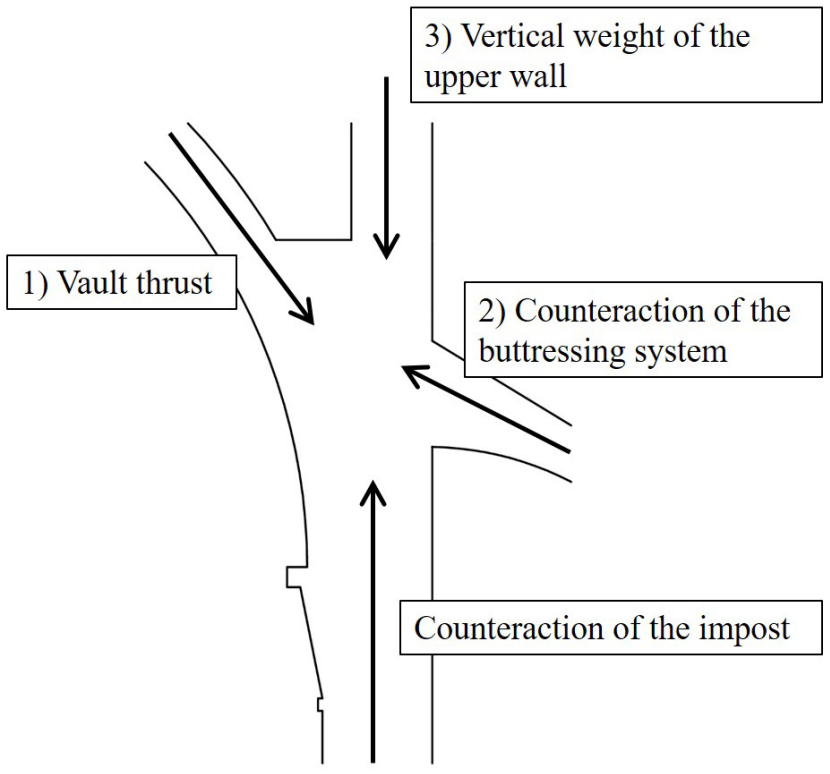

Fig. 3 Schema of the forces at the tas-de-charge.

Fig. 2 Positioning of multiple arches on an impost, vertically pushed by the upper wall: a) schema with separated arches, b) vault springer with separated ribs and double arch, c) schema with merged arches in the tas-de-charge type springer (after drawings from Viollet-le-Duc, 1854-1868 entry Construction / Voûtes). 
Tas-de-charge made vaulting execution easier and more economical. Rodrigo Gil de Hontañón (1500-1577), the master mason of such important Cathedrals like the one of Segovia or Salamanca described the steps of the construction of lierne vaults in his treatise from between 1544-1554 (Kubler, 1944; Huerta, 2002; Huerta, 2012; Pérez de los Ríos and Rabasa Díaz, 2014). Despite that this is a post-Gothic or so-called Early Modern Gothic treatise (see Taín-Guzmán et al., 2012), Hontañón's description of the vault erection process is highly relevant regarding early and high Gothic cross vaults as well. In his illustrated (Fig. 4) text, Hontañon indicated that the pillars and the tas-de-charge were the first to be built. Then a platform was to be constructed, at the level of the voussoirs' springing, at the top of the tas-de-charge. On this platform, the plan of the lierne vault had to be drawn to determine the position of the bosses of the lierne vault. At the next phase, the stone bosses were lifted to their proper height with wooden struts, and then the ribs could be built on the centring (Huerta and Ruiz, 2006). The process could be similar in early and high Gothic cross vaults, where there were no bosses, but only one keystone whose positioning was simpler.

As the voussoirs started to erect from a higher level, above the tas-de-charge, a lesser surface of the arches needed centring, resulting in more economical wood consumption. This meant a significant reduction in the

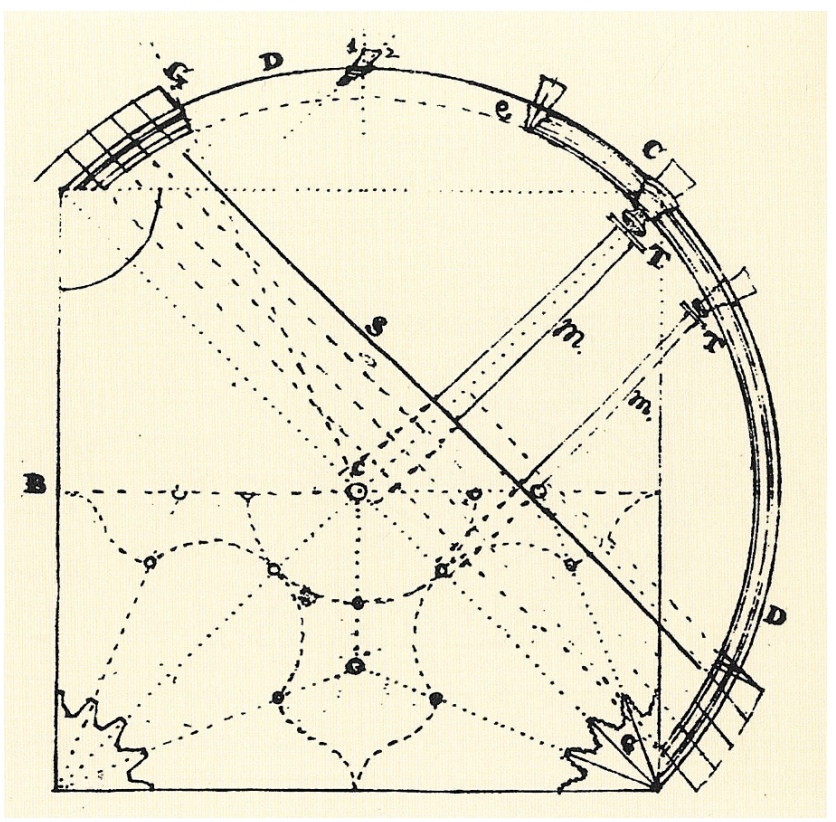

Fig. 4 Rodrigo Gil de Hontañón's drawing of vault construction with tas-de-charge. The level of the tas-de-charge type springers is indicated with a red dashed line (Huerta, 2012). construction costs, especially when the tas-de-charge was raised to the mid-height of the vault (Stanley, 2006). The building of the tas-de-charge represented the first phase of vault erection, separated from the stage of the construction of the voussoirs. Not only the construction, but even the design was better started with the tas-decharge. The geometry, positioning and method for jointing the structural elements had to be decided before the dimension and profile of the column shafts (for example, the of the case at the choir of the Cathedral of Narbonne, Freigang, 1989). Tas-de-charge could also act as a temporary support during the construction. In a basilica type building, the nave and the aisles were rarely vaulted in the same phase. As one of the experts invited to revise the construction of Segovia Cathedral in the $16^{\text {th }}$ century, Enrique Egas suggested to the builders, the aisle vaults were to be built first (Huerta and Ruiz, 2006). After that and before the finishing of the nave vaults with the flying buttresses, temporary supports were needed to balance the thrusts of the aisle vaults. At this point, the nave walls were to be erected till the clerestory windows together with the tas-de-charges, which provided enough downward vertical weight to temporarily buttress the aisle vaults (Huerta and Ruiz, 2006). The folio 31v of Villard de Honnecourt's sketchbook from the 13th Century likely shows the same stage of construction in the Cathedral of Reims (Fig. 5). Villard's drawing represents the nave wall's inner elevation under construction, with unfinished vaults (Barnes, 2009). The drawing showed the stage when the voussoirs were not yet built, but the tas-decharges were already placed.

\subsection{The height of the tas-de-charge}

The proper determination of the height of the tas-de-charge was a crucial design decision. The right height influenced the junction of the thrusts and loads. On the one hand, if the tas-de-charge was lower than the ideal, the buttresses would have born greater thrusts from the voussoirs, that were also more likely to slide sideward, after Viollet-le-Duc's argument (Fig. 2 (a)). On the other hand, the higher the tas-decharge was, the heavier and larger the upper course blocks became, significantly complicating their carving and lifting. The correct height also depended on the geometry of the pointed arches of the nerves. The higher tas-de-charge top being ideal with the narrower proportioned pointed arches. It also must be stated, that even if the arches were lighter, their lateral force may have increased, since the higher the springing level was, and the smaller the slope of the supporting 


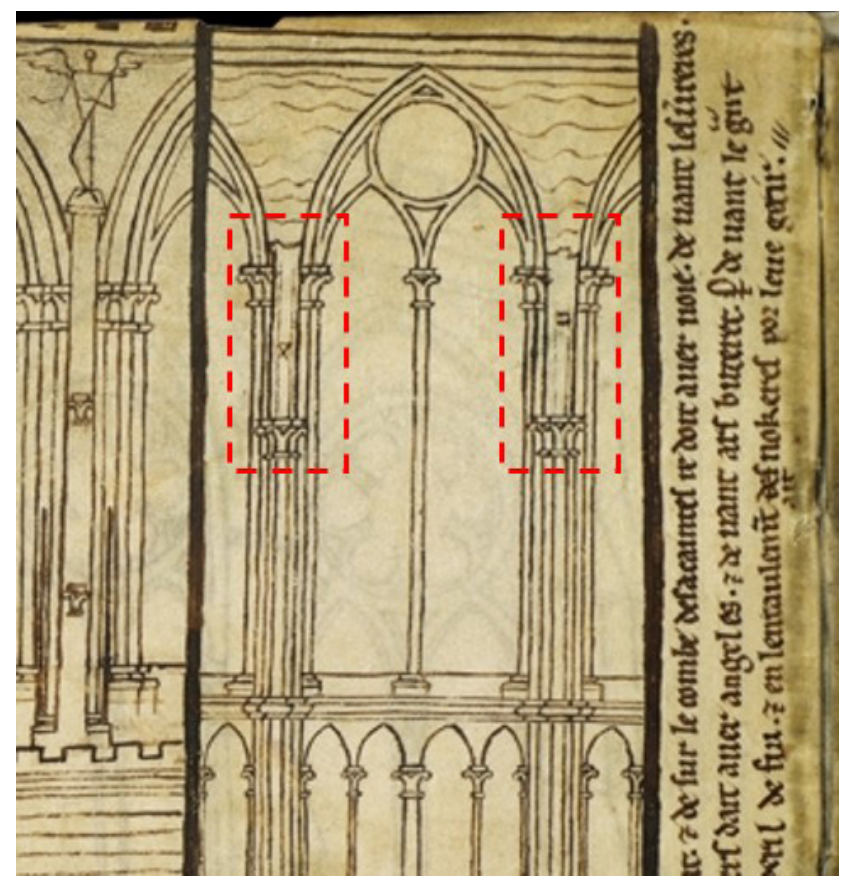

Fig. 5 Villard de Honnecourt's drawing of the inner elevation of the nave in Reims Cathedral under construction. The parts with the already built tas-de-charge type springers are indicated with red dashed lines (Barnes, 2009).

force of the arch. In Villard de Honnecourt's and Rodrigo Gil de Hontañón's drawing (Figs. 4 and 5), the tas-de-charge rise approximately one-third of the vault. According to David J. Stanley (2006), tas-de-charge could rise to half the height of the intrados. Rocío Maira Vidal found similar results from a survey of 59 sexpartite vaults in France, England, Spain, Germany, Switzerland and Italy. In Lincoln Cathedral and the Monasteries of Santa Maria de Huerta and Las Huelgas de Burgos, she found from 0.8 to 3 meter-high tas-de-charges of ca. seven to thirteen courses, rising even higher than the mid-height of the total intrados (Maira Vidal, 2017). Pablo Moreno Dopazo (2016) found similarly high tas-de-charges in the crossing of the chapel of Archbishop Fonseca College in Salamanca, produced by Rodrigo Gil de Hontañón between 1547-1549. These examples show that Gothic master masons tended to raise the tas-de-charge to the middle of the arches' total height.

\subsection{Connection of the buttressing system and the tas-de- charge}

As mentioned above, the massive of the tas-de-charge where the blocks were bound to the wall represented a junction area of multiple thrusts and weights to be balanced by the counteraction of the buttressing system (Fig. 3). This means that, in theory, the tas-de-charge and the buttressing system should be in direct connection. This was the case in several Gothic cathedrals, but in some other cases, masters failed to realise this structural coincidence. Medieval master masons' constructional knowledge was strongly practical and experimental. They learnt from their own or other masters' failures (see Mark and Clark, 1984). Flying buttresses answered an important architectural demand, namely the vault's support while unblocking the lighting through the clerestory windows. However, it was soon experienced that, in high Gothic cathedrals, support was needed at more than one point, to support the wall and roof above the vault against the significant wind load (Borg and Mark, 1973). The buttressing system became more complicated by an additional flyer, where the lower flyer provided support against the vault thrust, and the upper one resisted the wind effect (Fitchen, 1955; Heyman, 1967). In this system, the exact position of the lower flyer was not irrelevant at all. According to Jacques Heyman (1966), for the most efficient support, 'ideally, the head of the [lower; the author] flying buttress should lie about halfway between the springing and the crown of the vault'. As was mentioned in Subsection 2.3, the height of the tas-de-charge tended to rise up to the mid-point of the vault intrados, just as in Heyman's statement about the ideal height of the lower buttress flyer. In other words, in a correctly designed Gothic skeletal system, the level of the lower flyer head from outside should be right at the level of the top course of the tas-de-charge from inside (Fig. 6). Their direct connection is adequate from the aspect of the balance of the forces: the arch of the flyer supports the upper tas-de-charge stone, which is pushed laterally by the maximum thrust from the voussoirs (Fig. 3). For the structure's equilibrium, the wall's downward vertical weight also played an indispensable role (Deneux, 1943).

Henri Deneux (1943) found this system of direct connection between the lower flyer head and the top stone of

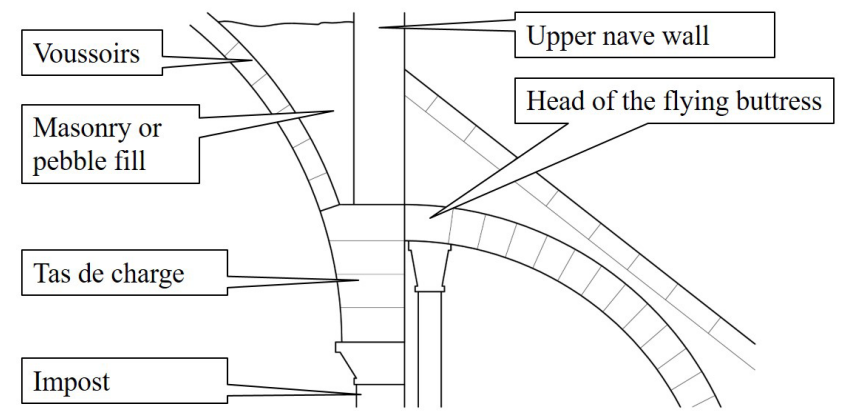

Fig. 6 Schema of the proper connection of the tas-de-charge and the flying buttress (after Fitchen, 1955). 
the tas-de-charge in the choir (c. 1220) and nave (c. 1240) of the Cathedral of Reims, in the choir of the Cathedral of Amiens (c. 1260), in the Cathedral of Beauvais (after 1225) (Fig. 7), and later examples, like the Church of Moret (early $13^{\text {th }}$ Century), the choir of the Church of Conty and Saint-Riquier (15th Century), and the nave of Saint Ouen in Rouen (15th Century) (Deneux, 1943; for Beauvais see also Heyman, 1967). Deneux (1943) also identified, that the same logic was used in the lower chapel of Sainte-Chapelle in Paris, where the central vaults were supported exactly at the top of the tas-de-charge by struts in the aisles (Fig. 7 (e)). However, he found that the system was not applied in the nave of the Cathedral of Amiens and Chartres, where the flyer heads correspond to the level right above the capitals (Deneux, 1943). Quite a large variety of positions of the lower flyer head can be observed in early and high Gothic cathedrals compared to the top of the tasde-charge (Borg and Mark, 1973). The Cathedral of Reims was one of the earliest examples where the direct connection of the tas-de-charge and the lower flyer head was knowingly realised both in the nave and the choir (Fig. 7 (a) and (b); Deneux, 1943; Mark and Clark, 1984). In this sense, it is worth mentioning the drawing of the cross-section of the choir of Reims Cathedral on the folio $32 \mathrm{v}$ of Villard de Honnecourt's sketchbook (Fig. 8; Barnes, 2009), that contains some differences compared to the actual building. Among these, the lower flyer was drawn as high as the capital of the impost, or even a bit lower, while in the actual building it corresponds to the top course of the tas-de-charge (Clark, 2004). The mistake was realised and commented by Robert Branner (1963) and later by Carl F. Barnes (1989). Barnes (1989) considered this
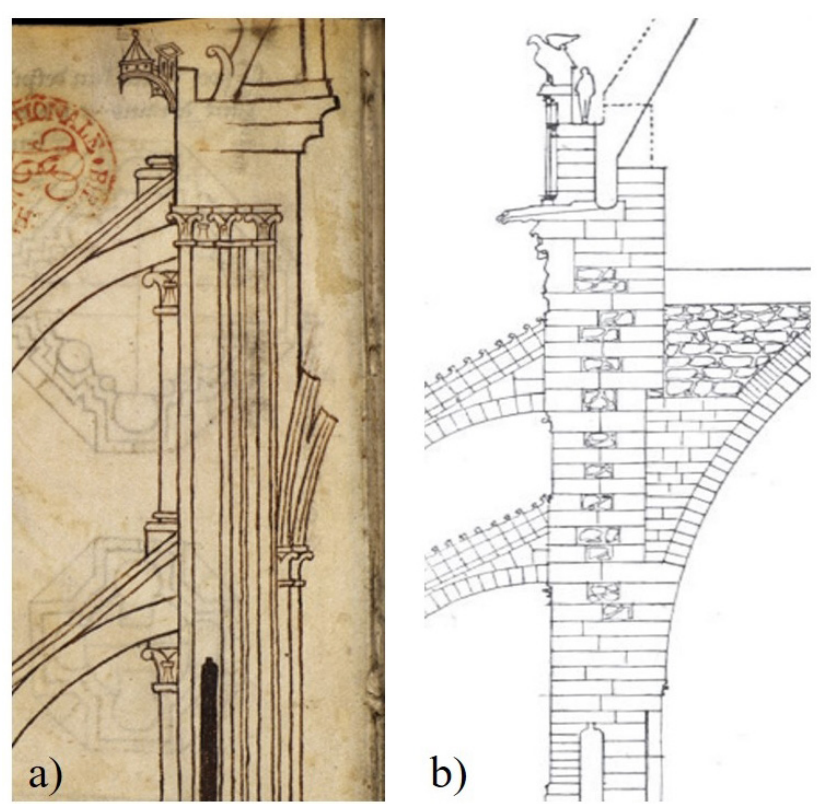

Fig. 8 Cross sections showing the flying buttresses and the tas-decharge of the choir of Reims Cathedral: a) Villard de Honnecourt's drawing (Barnes, 2009), b) drawing from Deneux, 1943.

mistake as proof of Villard de Honnecourt not being an architect, claiming that a master mason would have understood the system of levels of the flyers and the clerestory window. Indeed, the drawing reveals that Villard really missed the importance of the direct relation of the tas-decharge and the flying buttress. Sharing Barnes's argument, an architect would have understood, or at least noticed and correctly drawn this crucial relation of structural elements.

The link between the upper course of the tas-decharge can also be direct with buttress piers, as was convincingly indicated in the Unterweisung (1516) of
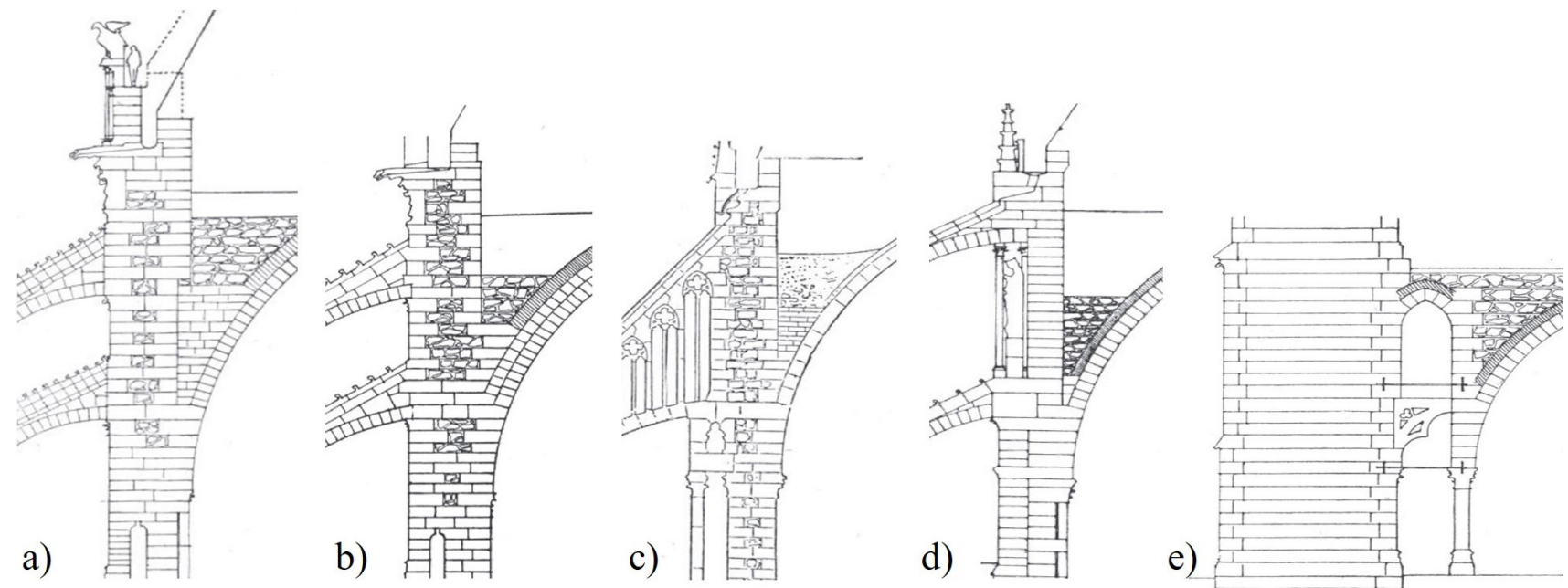

Fig. 7 Cross section of a) the choir of the Cathedral of Reims, b) the nave of the Cathedral of Reims, c) the choir of the Cathedral of Amiens, d) the choir of the Cathedral of Beauvais, e) and the lower chapel of Saint Chapelle (drawings from Deneux, 1943). 
Lorenz Lechler, the late Gothic master mason from BadenWürttemberg (Fig. 9; Shelby and Mark, 1979). Lechler's text is sometimes challenging to understand, but the interpretation of Lon R. Shelby and Robert Mark (1979) seems to be reliable. According to them, Lechler correctly understood that the buttress's most load-bearing point had to be as high as the top tas-de-charge course. Lechler suggested the design as the following: 'Make ein Richtung and set it behind the tas-de-charge which stands on the springer [in this text the term tas-de-charge stands for the top course, and the term springer means the lower courses; the author]. You should let the Richtung go out as far as the length of the buttress so that the buttress becomes a square' (translated by Shelby and Mark, 1979). Shelby and Mark (1979) interpreted the term Richtung as the stone course, that extended through the buttress thickness, from the top tas-de-charge course to the outer elevation (Fig. 9). Thus, thanks to its form, with its horizontal lower bed and its inclined upper beds, the top course transformed the vault thrust to the stones of the Richtung. The Richtung could resist the thrust with its thickness and by the weight of the buttress from above.

\subsection{Design and execution of the tas-de-charge}

The tas-de-charge geometry is rather complicated, as the transversal arch, ribs and formerets with different radii and sometimes profiles have to be spatially merged or intersected while they are continually springing in each course. Additionally, the horizontal joints distort the profiles. The carving of the average voussoirs was simple by using one single template for their cross-section. This standard template was used naturally for the voussoirs' radial joints, at a right angle to their curvature. The carving and design of the tas-de-charge courses demanded more advanced stereotomic knowledge because, in theory, the profiles become distorted in the horizontal joints.

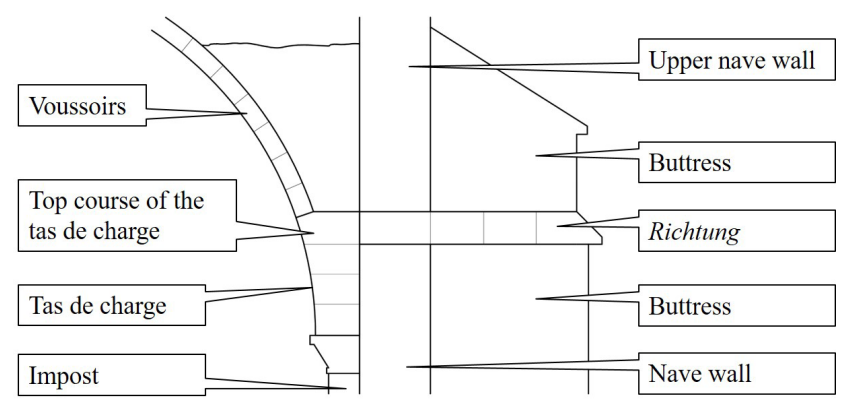

Fig. 9 Schema of the proper connection of the tas-de-charge and the buttress (after Shelby and Mark, 1979).
Many scholars have been interested in the design and execution of tas-de-charge courses. According to Robert Willis (1842), who investigated several tas-de-charge elements in the ruined crossing tower of Canterbury Cathedral, the blocks' geometrical construction was worked out on the stone surface itself. Willis stated that first all the axes of the merging nerves were traced on the upper and lower beds of each stone course. The standard templates without any distortion were then traced on the stone, one after the other, successively hiding some mouldings from the former. Willis argued that the master mason only had to measure the displacement of the intrados on each bed, and then he could use the standard templates without any elongation. He claimed that the difference of the length of the profiles cut horizontally and radially was so small, and the vault springers were far enough from the observer, that it could not be noticed (Willis, 1842). Opposed to Willis, Violletle-Duc (1854-1868 entry Construction) declared, that the templates were stretched in the horizontal joints. The question was later investigated by Nicholas Webb, Alexandrina Buchanan and John Robert Peterson (2016) at the tas-decharges of the Chapter House at Chester Cathedral, the south nave arcade in Exeter Cathedral, and the choir aisle of Wells Cathedral. The scholars intended to verify the correctness of Willis's statement about the non-distorted profiles. Their measurements based on laser scanning found no significant adjustment in the horizontal sections (Webb et al., 2016; Webb and Buchanan, 2017). However, Rocío Maira Vidal's study of 59 examples with sexpartite vaults ended with the opposite result. She deduced that individually elongated templates were created for each bed in the tas-decharge (Maira Vidal, 2017). Luc Mojon (1986) identified a slightly different process in the midway. He found that the standard templates were used without adjustment until a certain height, till the difference of the regular and elongated profiles was impossible to notice. Above that level, where the difference became visible, profiles were stretched. Carmen Pérez de los Ríos and Enrique Rabasa Díaz (2016) deduced similar results by the detailed investigation of the tas-de-charges of the Theology Room in The Palace of the Popes of Avignon. Essentially, they shared Maira Vidal's opinion that each bed had its own individually stretched template. However, they found that profiles were not elongated in the lower beds, but above a certain level, they could measure up to six $\mathrm{cm}$ of difference between the regular and the distorted profiles (Pérez de los Ríos and Rabasa Díaz, 2016).

It seems that in the Middle Ages, all the solutions existed. Certain master masons used the average templates 
without distortion, others created stretched templates for each bed, or they applied these design methods dynamically according to the size and height of the tas-de-charge. This problematic of profile adjustment was a focus of interest of the authors of Early Modern treatises. In the $17^{\text {th }}$ Century, Joseph Gelabert described and illustrated the cutting of stretched templates for each course of the tas-de-charge (Pérez de los Ríos and Rabasa Díaz, 2014). Rodrigo Gil de Hontañón and Alonso de Vandelvira also wrote about the proper geometrical transformation of rib profiles (Pérez de los Ríos and Rabasa Díaz, 2014). Amadée-Francois Frézier, in the $18^{\text {th }}$ Century, explained the tracing of the profiles in the horizontal courses, where some of the mouldings are hidden by the others, as the arches are merged. Thus, the transformation of stretched profiles was a commonly referred and illustrated geometrical operation in Early Modern treatises in the $16-18^{\text {th }}$ Century (Pérez de los Ríos and Rabasa Díaz, 2014); however, there is no evidence that any of these operations would have been applied during the Middle Ages. Indeed, the operation of medieval masters somewhat lacked these theory-based geometrical methods, which were clearly popular in the Early Modern treatises.

On the contrary, the medieval masters' geometry was much more practical. As Willis (1842) suggested, and Webb et al. (2016) confirmed, medieval architects could basically use standard templates, and if corrections were needed, they could easily play with carving, according to the particular situation. This is why we can find interestingly various and individual solutions for the same design problem (e.g. the vault springer) even within the same building (see Webb et al., 2016). Opposed to this approach, the authors of Early Modern or post-Gothic treatises regarded Gothic design problems as theoretical questions. For writers such as Frézier, Hontañón, Gelabert or Vandelvira, the stretching of the templates for the tas-de-charge joints meant proper, theory-based geometrical transformations. As Willis (1842) summarised, this abstract, theory-based approach was the idea, that essentially distinguished Gothic architectural design from Modern and neo-Gothic.

\section{Early Hungarian examples}

In the Hungarian historiography, the topic of tas-de-charge, or the early and high Gothic vault springers has not yet been researched. However, it seems that early forms of tas-decharge had already been applied in Hungary as early as our first Gothic monuments. The Palatine Chapel of Esztergom is considered the first appearance of Gothic architecture in Hungary (Marosi, 1984). In the last decades of the $12^{\text {th }}$ Century, by order of Béla III, the construction of the Palatine Chapel of Esztergom was indeed carried out by a workshop coming directly from Northern France (Marosi, 1984). In the nave, the vault springers were not created with tasde-charge, but in the apse, the idea of tas-de-charge was visibly applied (Fig. 10). Here, the springers are in a particular situation, as the vault ribs of the polygonal apse rest on double columns drawn in front of the wall. The nerves of the rib and the formerets are intersected in the first couple of courses, enabling the columns to be very elegantly narrow. The formerets of the polygonal apse are formed by so tall and narrow pointed arches, that their curvature at the springing point begins not immediately above the impost, but from the top of a vertical section of two stone courses. Above the springing point, in the third course, the arches start to spring, but the nerves are still merged, and the top joint is horizontal (Fig. 11).

Two decades after the Palatine Chapel of Esztergom, the rebuilding of the Benedictine Archabbey of Pannonhalma also resulted in an important Gothic construction in

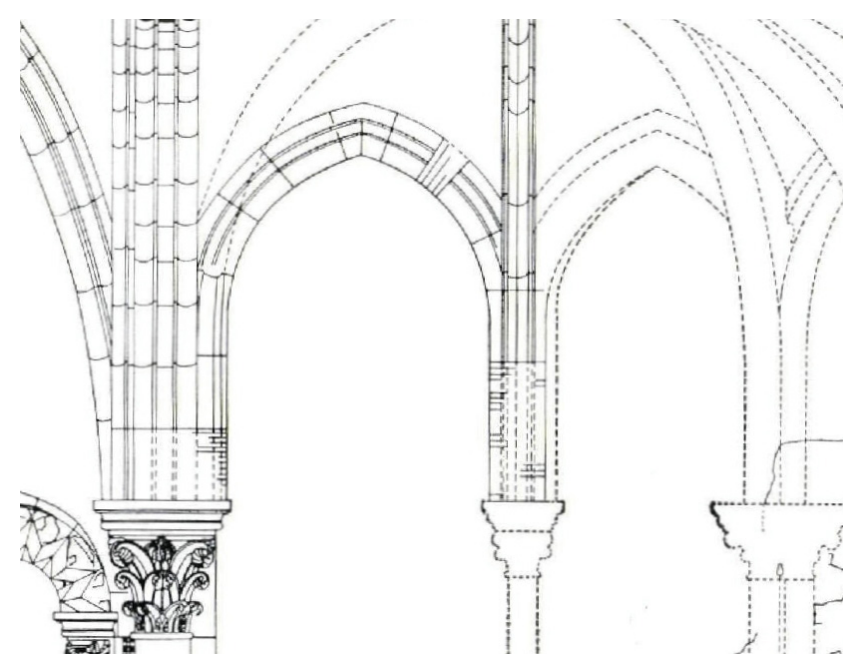

Fig. 10 Detail of Dezső Várnai's drawing of the Palatine Chapel of Esztergom (Várnai, 1974).

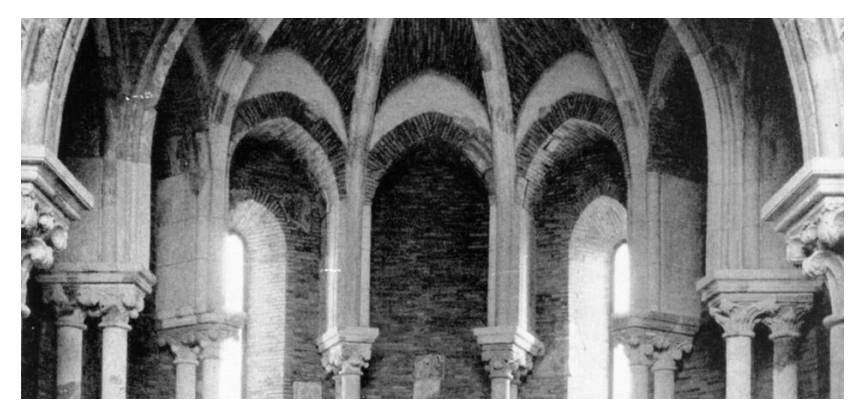

Fig. 11 Detail of the apse vault of the Palatine Chapel of Esztergom after Kálmán Lux's reconstruction (Nagy, 2018). 
Hungary. The works began around 1210 and finished by the consecration in 1224 (Takács, 1996). According to Imre Takács's latest periodisation, several groups of masters were hired and fired one after the other, during the construction (Takács, 1996). According to Takács (1996), the first lodge finished the crypt, the main sanctuary, and the southern aisle's first eastern bay. They indeed had a plan for the nave vaults, as they started to construct its first stones. For unknown reasons, they could not continue their work, and later another lodge finished the nave vaults by a different concept. The first lodge knew and applied tasde-charge type vault springers. They applied it in the rib vaults of the crypt, where the lower course joints are not consequently horizontal at each springer, but the nerves are all merged. This solution is perfectly adequate in the crypt-hall, where four double arches and four transversal ribs spring from the top of the central columns. Placing all these eight arches side by side would have required an unreasonably large surface on the top of the capitals. This lodge would also have applied tas-de-charge in the nave vaulting if they could have finalised it according to their concept. This is clear from two springer stones in the nave's eastern corners on both sides, right in front of the triumphal arch. The stones were built in by the first lodge but modified by a later lodge, who were also responsible for the nave vaults. According to Márton Sarkadi's survey drawing in Fig. 12, on the northern side of the nave wall, these stone courses had a horizontal bed, and the rib was merged

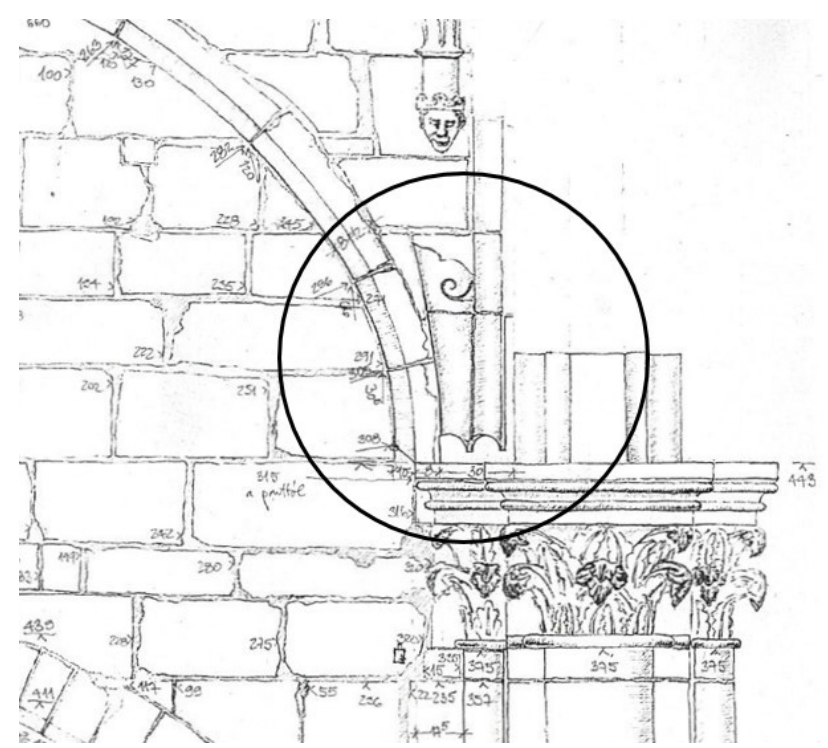

Fig. 12 Detail of Márton Sarkadi's drawing of the northern nave wall of the Archabbey of Pannonhalma showing the springer elements built by the first lodge, and modified by the later lodge finishing the nave vaults (Takács, 1996). with the western layer of the transversal arch in one single block (Fig. 12). The lodge, who finished the nave vaults followed another concept. In their sexpartite vaults, all the nerves sprang from different levels (Takács, 1996).

The third, rather early example of tas-de-charge in Hungary can be found in the Premonstratensian Church of Zsámbék. It was built in the first half of the $13^{\text {th }}$ Century and shared late Romanesque and early Gothic characteristics. The Church of Zsámbék can be considered as the earliest known and still (partially) standing example, where tasde-charge with its all principles were constructed, both the nave and the aisles (Fig. 13). In the ruined church, it is not by accident that the vaults usually remained till the top of the tas-de-charges (not counting the reconstructed elements), as they were one of the most massive parts of the construction.

As the number of the original remaining early Gothic monuments in Hungary is quite limited, it is difficult to determine the first application and early development of tas-de-charge in Hungary. As it was highly effective in halls, like the crypt of Pannonhalma, where several large nerves had to be placed on one central impost, tas-decharge was a possibly used solution even in this early period. The knight hall of the Castle of Léka is a representative example for early tas-de-charge, merging simple arches without mouldings (Fig. 14).

\section{Conclusion}

The tas-de-charge was a particular type of springer in early and high Gothic ribbed vaults. It played an indispensable role in balancing the vault thrusts, while allowing

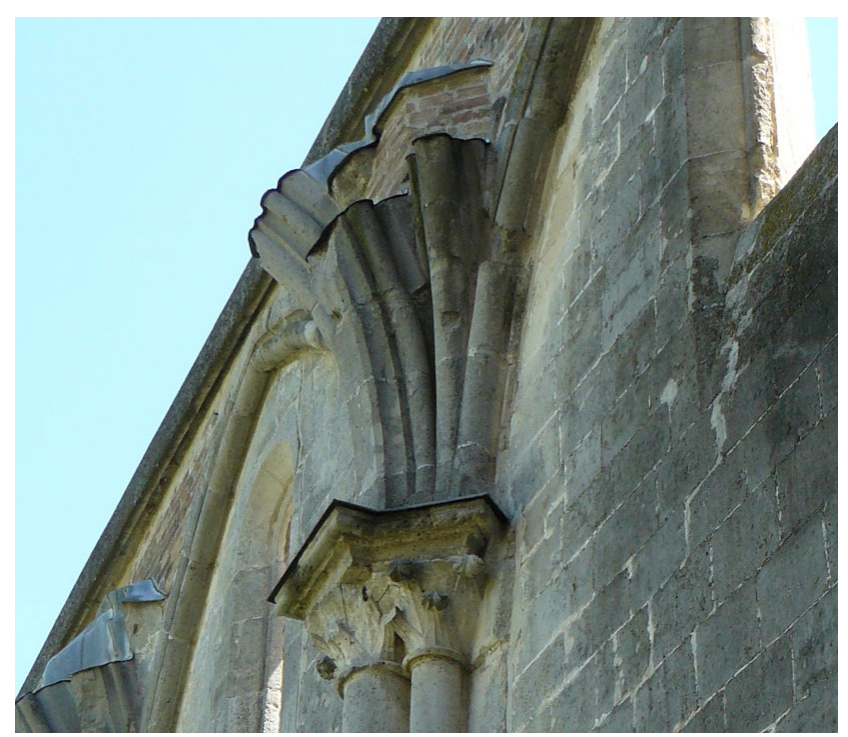

Fig. 13 Tas-de-charge type vault springer in the nave of the Church of Zsámbék. 


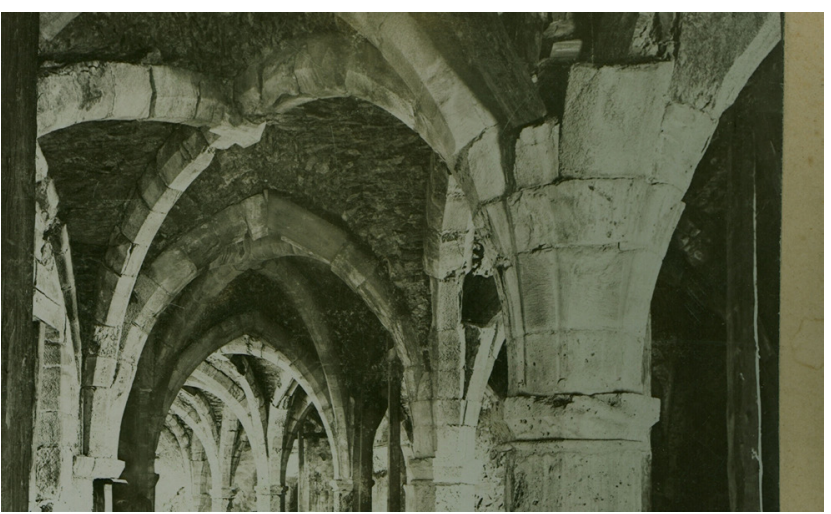

Fig. 14 Tas-de-charge type vault springers in the knight hall of the Castle of Léka (Plan Collection and Archives of BME Department of History of Architecture and Monument Preservation, ref. no. 800828).

the design of narrow, but still strongly load-bearing structures. The application of tas-de-charge manifests a high standard of stereotomic knowledge and the Gothic builders' structural sense. It testifies, that master masons were aware of the overall behaviour of the whole structural system and designed the smallest of details, even individual stone elements in regard to the equilibrium and proportions of the building. This was especially the case when the direct connection of the buttressing system and the

\section{References}

Barnes, C. F. (1989) "Le 'problème' Villard de Honnecourt" (The Villard de Honnecourt 'problem'), In: Recht, R., Le Goff, J. (eds.) Les bâtisseurs des cathédrales gothiques, Les Musées de la ville de Strasbourg, Strasbourg, France, pp. 209-223. (in French)

Barnes, C. F. (2009) "The Portfolio of Villard de Honnecourt. A New Critical Edition and Colour Facsimile", Routledge, London, UK. https://doi.org/10.4324/9781315237657

Bond, F. (1906) "Gothic Architecture in England", B. T. Batsford, London, UK.

Borg, A., Mark, R. (1973) "Chartres Cathedral: A Reinterpretation of its Structure", The Art Bulletin, 55(3), pp. 367-372. https://doi.org/10.2307/3049125

Branner, R. (1962) "Paris and the Origins of Rayonnant Gothic Architecture down to 1240", The Art Bulletin, 44(1), pp. 39-51. https://doi.org/10.2307/3047984

Branner, R. (1963) "Villard de Honnecourt, Reims and the Origin of Gothic Architectural Drawing", Gazette des Beaux-Arts, 61, pp. 129-146.

Clark, W. W. (2004) "Reims Cathedral in the Portfolio of Villard de Honnecourt", In: Zenner, M. T. (ed) Villard's Legacy. Studies in Medieval Technology, Science and Art in Memory of Jean Gimpel, Routledge, London, UK, pp. 23-51. https://doi.org/10.4324/9781315235028

Deneux, H. (1943) "De la construction en tas-de-charge et du point de butée des arcs-boutants au Moyen Âge" (About the construction with tasde-charge and the abutment point of flying butresses in the Middle Ages), Bulletin Monumental, 102(2), pp. 241-256. (in French) tas-de-charge was knowingly achieved. Tas-de-charge has also been applied in the early Gothic architecture of Hungary. The most complete example can be observed in the ruined Church of Zsámbék, sharing late Romanesque and early Gothic features. Regarding the topic of vault springers and the tas-de-charge, the further review of high Gothic Hungarian examples, as well as their detailed analysis could represent a progressive direction for future research, in order to form a more complete picture regarding the various applications and development of tas-decharge in the history of Hungarian Gothic architecture.

\section{Acknowledgement}

I am grateful to István Sajtos PhD for his valuable help during the research. The research was supported by the ÚNKP-19-3 New National Excellence Program of the Ministry for Innovation and Technology.

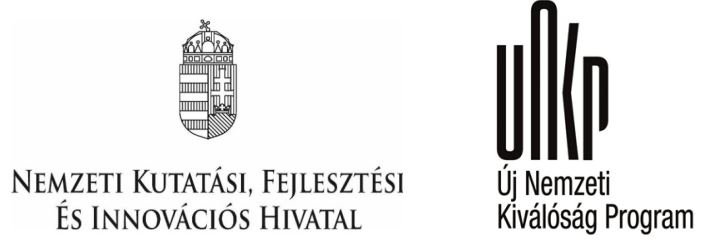

Fehér, K. (2017) "Relations architecturales du château de Hunedoara et du Palais de Ducs de Bourgogne dijonnais au milieu du XVe siècle particulièrement en matière des naissances des voûtes" (Architectural relations between the castle of Hunedoara and the Palace of the Dukes of Burgundy in Dijon in the middle of the XVth century, particularly in the question of the vault springers), Acta Neerlandica: Bijdragen Tot de Neerlandistiek Debrecen, 14, pp. 65-88. (in French)

Fitchen, J. (1955) "A comment on the function of the upper flying buttress in French Gothic architecture", Gazette des Beaux-Arts, 45(6), pp. 69-90.

Freigang, C. (1989) "Le Chantier de Narbonne" (The construction of Narbonne), In: Recht, R., Le Goff, J. (eds.) Les bâtisseurs des cathédrales gothiques, Les Musées de la ville de Strasbourg, Strasbourg, France, pp. 127-131. (in French)

Heyman, J. (1966) "The stone skeleton", International Journal of Solids and Structures, 2(2), pp. 249-256. https://doi.org/10.1016/0020-7683(66)90018-7

Heyman, J. (1967) "Beauvais Cathedral", Transactions of the Newcomen Society, 40(1), pp. 15-35. https://doi.org/10.1179/tns.1967.002

Holton, A. (2006) "The Working Space of the Medieval Master Mason: the Tracing Houses of York Minster and Wells Cathedral", In: Proceedings of the Second International Congress on Construction History, Cambridge, UK, pp.1579-1597. 
Huerta, S. (2002) "The medieval 'scientia' of structures: the rules of Rodrigo Gil de Hontañón", In: Becchi, A., Foce, F., Corradi, M., Pedemonte, O (eds.) Towards a History of Construction. Between Mechanics and Architecture, Birkhäuser Verlag, Basel, Switzerland, pp. 567-585.

Huerta, S. (2012) "Technical Challenges in the Construction of Gothic Vaults: The Gothic Theory of Structural Design", In: Construction Techniques in the Age of Historicism. From Theories of Gothic Structures to Building Sites in the 19th Century, Hirmer, Munich, Germany, pp. 162-195.

Huerta, S., Ruiz, J. A. (2006) "Some notes on gothic building processes: The expertises of Segovia Cathedral", In: Dunkeld, M., Campbell, J., Louw, H., Tutton, M., Addis, B., Thorne, R. (eds.) II International Congress on Construction History, London, UK, pp. 1619-1632.

Jansen, V. (1982) "Dying Mouldings, Unarticulated Springer Blocks, and Hollow Chamfers in Thirteenth-Century Architecture", Journal of the British Archaeological Association, 135(1), pp. 35-54. https://doi.org/10.1179/jba.1982.135.1.35

Kubler, G. (1944) "A Late Gothic Computation of Rib Vault Thrusts", Gazette des Beaux-Arts, 25(6), pp. 135-148.

Maira Vidal, R. (2017) "Evolution of construction techniques in the Early Gothic: Comparative study of the stereotomy of European sexpartite vaults using new measurement systems", Journal of Cultural Heritage, 28, pp. 99-108. https://doi.org/10.1016/j.culher.2017.05.005

Mark, R., Clark, W. W. (1984) "Gothic Structural Experimentation", Scientific American, 251(5), pp. 176-185.

Marosi, E. (1984) "Die Anfänge der Gotik in Ungarn: Esztergom in der Kunst des 12.-13. Jahrhunderts" (The beginnings of Gothic in Hungary: Esztergom in the art of the 12-13th century ), Akadémiai Kiadó, Budapest, Hungary. (in German)

Mojon, L. (1986) "Analyse eines spätgotischen Tas-de-charge" (Analysis of a late Gothic tas-de-charge), In: St. Johannsen Saint-Jean de Cerlier. Beiträge zum Bauwesen des Mittelalters aus den Bauforschungen in der ehemaligen Benediktinerabtei, 1961-1984, Staatlicher Lehrmittelverlag, Bern, Germany. (in German)

Moreno Dopazo, P. (2016) "Rodrigo Gil de Hontañón and 16th-Century Building Techniques: The Cimborio Vault of Archbishop Fonseca College Chapel in Salamanca (Spain)", International Journal of Architectural Heritage, 10(8), pp. 1110-1124. https://doi.org/10.1080/15583058.2016.1187778

Nagy, E. (2018) "Az esztergomi királyi palota" (The royal palace of Esztergom), Magyar Nemzeti Múzeum Esztergomi Vármúzeuma, Budapest, Esztergom, Hungary. (in Hungarian)

Pérez de los Ríos, C., Rabasa Díaz, E. (2014) "Stretched templates in Gothic tas-de-charge construction", In: Campbell, J. W. P., Andrews, W., Bill, N., Draper, K., Fleming, P., Pan, Y. (eds.) Proceedings of the First Conference of the Construction History Society, Construction History Society, Cambridge, England, pp. 333-342.

Pérez de los Ríos, C., Rabasa Díaz, E. (2016) "Innovations constructives gothiques dans le palais des Papes d'Avignon: tas-de-charge avec des croisements" (Gothic constructive innovations in the Palace of the Popes of Avignon: tas-de-charge with crossings), In: Fleury, F., Baridon, L., Mastrorilli, A., Mouterde, R., Reveyron, N. (eds.) Les temps de la construction. Processus, acteurs, matériaux, Picard, Paris, France, pp. 689-698. (in French)
Rabasa-Díaz, E. (2018) "Late Gothic system in the church of Saint-Séverin (Paris)", In: Wouters, I., van de Voorde, S., Bertels, I., Espion, B., de Jonge, K., Zastavni, D. (eds.) Building Knowledge, Constructing Histories, CRC Press, Boca Raton, FL, USA, pp. 1083-1087.

Senent Domínguez, R., Rodríguez, M. Á. A., Rabasa Díaz, E., Calvo López, J. (2012) "The Irregular Ribbed Vault of the Sacristy of the Cathedral of Saint-Jean Baptiste in Perpignan", In: Carvais, R., Guillerme, A., Nègre, V., Sakarovitch, J. (eds.) Nuts and Bolts of Construction History: culture, technology and society, Volume 3, Picard, Paris, France, pp. 75-82.

Shelby, L. R., Mark, R. (1979) "Late Gothic structural design in the 'instructions' of Lorenz Lechler", Architectura, 9(2), pp. 113-131.

Stanley, D. J. (2006) "The Original Buttressing of Abbot Suger's Chevet at the Abbey of Saint-Denis", Journal of the Society of Architectural Historians, 65(3), pp. 334-355.

https://doi.org/10.2307/25068292

Taín-Guzmán, M., Alonso-Rodríguez, M. A., Calvo-López, J., Natividad-Vivó, P. (2012) "Stonecutters' literature and construction practice in early modern Gothic: The tracings for a rib vault at the cathedral of Tui in Galicia", Construction History, 27, pp. 1-21.

Takács, I. (1996) "Pannonhalma újjáépítése a 13. században" (The rebuilding of Pannonhalma in the 13th century), In: Takács, I. (ed.) Mons Sacer 996-1996. Pannonhalma 1000 éve, Volume I, Pannonhalmi Bencés Főapátság, Pannonhalma, Hungary, pp. 170-236. (in Hungarian)

Várnai, D. (1974) "Az esztergomi királyi palota építési szakaszai" (The construction phases of the royal palace of Esztergom), In: Magyar Mủemlékvédelem 1971-1972, Országos Mủemléki Felügyelőség, Budapest, Hungary, pp. 75-102. (in Hungarian)

Viollet-le-Duc, E. E. (1854-1868) "Dictionnaire raisonné de l'architecture française du XIe au XVIe siècle" (Rationale dictionary of French architecture from XIth to XVIth century), Bance-Morel, Paris, France. (in French)

Melchior de Vogüé, D., Neufville, D. J. (1971) "Glossaire de termes techniques à l'usage des lecteurs de la nuit des temps" (Glossary of technical terms for the use of readers of the dawn of time), Zodiaque, Saint-Léger-Vauban, France. (in French)

Webb, N., Buchanan, A., Peterson, J. R. (2016) "Modelling Medieval Vaults: Comparing Digital Surveying Techniques to Enhance our Understanding of Gothic Architecture", In: Aulikki, H., Österlund, T., Markkanen, P. (eds.) Complexity \& Simplicity - Proceedings of the 34th eCAADe Conference, Oulu, Finland, pp. 493-502.

Webb, N., Buchanan, A. (2017) "Tracing the past: A digital analysis of Wells cathedral choir aisle vaults", Digital Application in Archaeology and Cultural Heritage, 4, pp. 19-27. https://doi.org/10.1016/j.daach.2017.01.001

Willis, R. (1842) "On the Construction of the Vaults of the Middle Ages", Longman, Brown, Green, and Longmans, London, UK. 